\title{
Intergovernmental collaboration for the health and wellbeing of refugees settling in Australia
}

\section{Belinda Martina,b,c and Paul Douglas ${ }^{b}$}

a Australian Government Border Force, Canberra, ACT, Australia

b Department of Home Affairs, Canberra, ACT, Australia

c Corresponding author: belinda.martin@homeaffairs.gov.au

\section{Article history}

Publication date: March 2018

Citation: Martin B, Douglas P.

Intergovernmental collaboration for the health and wellbeing of refugees settling in Australia. Public Health Res Pract. 2018;28(1):e2811807. https://doi. org/10.17061/phrp2811807

\section{Key points}

- The health and wellbeing of refugees settling in Australia hinge on the identification of, and intervention for, health issues before migration. Collectively, the components of evidence based screening, high-performing clinical practice, premigration intervention and the availability of health information for postmigration continuity of care create effective premigration health screening

- Through collaboration between likeminded national governments to explore similarities and differences in refugee health screening, Australia benefits from the experience and evidence of other countries. Alignment with other countries improves the quality of health screening and services, and diagnostic capability

- The positive influence of this cooperation on Australia's refugee screening and offshore interventions contributes to improved health outcomes and wellbeing during the refugee settlement process

\section{Abstract}

As outlined in the Department of Immigration and Border Protection Annual report 2016-17, Australia granted 21928 humanitarian visas in 2016-17, 13760 of them offshore. This number will increase in future to a planned offshore program of 18750 in 2018-19. The report notes that the United Nations High Commissioner for Refugees ranks Australia third for the number of refugees resettled. With such a massive program and commitment by the Australian Government, the need to ensure that health and wellbeing are maintained or gained during the settlement process is paramount. This article outlines how collaboration between like-minded national governments can improve premigration health screening through information sharing, collaborative learning and increased capability in countries of origin to not only screen for illness and disability, but to more effectively put measures in place to address these before, during and after arrival. Australia, Canada, New Zealand, the UK and the US have worked together for more than a decade on migration health screening policies to ensure better management of health needs and successful resettlement. A case study about the Syrian refugee cohort, which began arriving in Australia in late 2015, illustrates how intergovernmental collaboration can improve settlement.

\section{Introduction}

Each year, approximately 15000 refugees who need humanitarian assistance are resettled in Australia through the offshore Refugee and Humanitarian Programme ${ }^{1}$, managed by the Australian Government Department of Home Affairs. This number will increase to a planned offshore program of 18750 by 2018-19. ${ }^{2}$ A proportion of those resettled have communicable, chronic or psychological health concerns. ${ }^{3,4}$ Management of health needs is fundamental to successful resettlement, and this begins before refugees arrive in Australia as part of premigration health screening (PMHS). 5,6 The effectiveness of PMHS for settlement hinges on robust evidence based screening, high-performing clinical practice and premigration interventions, in addition to postarrival continuity of care. 
Premigration management of refugee health must keep pace with the shifting complexity of differing refugee cohorts, coupled with growing volumes and ambitious political resettlement time frames. Understanding health issues in settling refugees is important so that we can appropriately respond to their needs and manage any risks through a continuum of care based on evidence. ${ }^{7}$ International collaboration between countries with similar programs, through shared learning and resources for improved health outcomes, helps us to understand and respond to premigration health issues.

This article draws on the experience of authors working in this area since 2006, as well as existing Department of Home Affairs policy and instruction documents that describe Australia's participation in the Immigration and Refugee Health Working Group (IRHWG). We also summarise how collaboration between national governments contributes to the health and wellbeing of refugees settling in Australia.

\section{Immigration and Refugee Health Working Group}

Australia, Canada, New Zealand, the UK and the US formed a voluntary forum in 2005 to discuss commonalities associated with PMHS services, contracted by all countries ${ }^{8}$ to the International Organization for Migration (IOM). The IOM is an intergovernmental organisation made up of 159 member states. It acts with its international partners to help meet the operational challenges of migration. A component of this work is to implement PMHS services on behalf of member states. The IOM employs panel physicians to administer, or oversee the administration of, comprehensive health screening services for all five countries. This promotes international standardised best practice in PHMS, thereby enhancing the quality and efficiency of these services for all participating countries. The forum was formalised in 2009 as the Migration Five (formerly known as the Five Country Conference).

The five IRHWG partners are the national health agencies in the US (Centers for Disease Control and Prevention) and the UK (Public Health England), and the three migration agencies in Australia, Canada and New Zealand, which have internal health departments. The IRHWG is a results-driven collaboration, characterised by its highly active and organised work program. This program has evolved from information sharing to combined quality assurance, greater combined management of the worldwide networks of panel member clinics and laboratories implementing $\mathrm{PMHS}^{6}$, and aspiring towards standardised guidelines.

\section{Premigration health screening}

PMHS is the medical examination required to assess an applicant's health against a legislative requirement so that they can be granted a visa to enter a country. In the Australian context, its main purpose, historically and now, is to prevent or limit the importation of threats to public health and avert excessive charges to the public system. ${ }^{8,9}$ PMHS is conducted by a panel consisting of locally qualified physicians, radiologists and tuberculosis (TB) laboratories operating according to Australian PHMS-specified guidelines in clinics within refugees' countries of displacement or transit, usually within refugee camps. There has been growing recognition that this presents a unique opportunity to address the health needs of individuals, rather than merely assessing health as a legislative requirement. ${ }^{8,10}$ In line with this, in 2012 Australia amended its policy so that refugee applicants can still be granted a visa, even if they require Government-funded health and community services that will incur excessive cost to the public system. Additionally, to secure continuity of care, systematic sharing of electronic PMHS records in English was established with onshore healthcare providers to improve resettlement of refugees with serious medical conditions.

There are no international standards for PMHS, although, as indicated earlier, there is a desire to develop them. Australia has similar standards and requirements to Canada and New Zealand, with the addition of a tuberculin skin test or interferon gamma release assay as an initial test for active TB in children younger than 11 years of age. Australia also has mental health screening and vaccination for refugees, consistent with standards that the US and the UK have recently introduced for refugee cohorts.

\section{Intergovernmental collaboration}

\section{Information exchange}

In 2005, IRHWG cooperation consisted primarily of information exchange about PMHS. An example of collaboration to better understand the health of refugees was data sharing by the US that showed elevated blood lead levels that were eight times higher than the US prevalence in resettled Burmese refugee children. The elevation was caused by premigration exposure to car batteries and contaminated traditional medicines. ${ }^{11,12}$ This led to premigration interventions, as well as the US engaging the IRHWG to disseminate its data. At that time, one-third of Australia-bound refugees came from the Burma region ${ }^{13}$, so Australia capitalised on the shared data and action to minimise the risk of lead harm to refugees resettling here.

Another illustration of information exchange is the process of transferring PMHS records to healthcare providers in the destination country, improving ongoing postarrival care. Informed by US and UK PMHS manual practices, Australia captured greater clinical detail to improve its PMHS electronic records and strengthen the continuation of clinical care postarrival. This electronic platform will be made accessible to all refugee healthcare providers in Australia, and has been adopted by four of the five IRHWG countries. 


\section{Collaborative learning}

Differences in focus and practice can also result in mutual benefit when the experiences of other IRHWG members inform alternative PMHS approaches. ${ }^{14}$ The inclusion of a skin condition assessment, and treatment for scabies and lice, is a recent PMHS policy change for Australiabound refugees. This was influenced by the practices of other IRHWG countries and by evidence of a high prevalence of untreated skin conditions leading to ill health in Syrian refugees in Jordan. ${ }^{4}$ Evidence provided by other IRHWG members can also help to create better practices in PMHS. An example is Australia's malaria test-and-treat approach, which is distinct from the presumptive treatment strategy used for US-bound refugees from malaria-endemic areas. In the Australian approach, all positive travellers and family members are followed up within 72 hours of arrival in Australia. ${ }^{15}$ Diverse approaches by member countries to malaria management of refugees resettled from malaria-endemic areas have led to a proposal to undertake research on these different protocols, to allow an evidence based best-practice approach. ${ }^{16}$

\section{Capability building}

For all IRHWG countries, the effectiveness of PMHS relies on high-performing clinical practice. Undiagnosed, misdiagnosed or underdiagnosed conditions can affect refugees' health before migration and delivery of services during settlement. Responsibility for the delivery of PMHS resides with the panel, who are local health professionals. However, accountability for mitigating risks remains a sovereign one for each IRHWG member. ${ }^{6}$ Risks are mitigated through a combination of targeted onsite audits, regional training and desktop auditing. To jointly manage these risks, Australia and New Zealand entered into an agreement to align and use a single panel. This channels a greater number of Australian and New Zealand PMHS cases to an aligned panel, which produces specialisation in refugee PMHS requirements, which benefits countries before and after arrival through strengthened panel capability. This enables shared resources between Australia and New Zealand for developing skills and knowledge in PMHS to expected standards. Onsite auditing examines competency and capability in applying PMHS guidelines. Australia's auditing rate is relatively low, with approximately $20 \%$ of the panel audited annually, because of the size of the panel. Alignment enables all countries to share auditing workloads, alleviate resource constraints, identify areas of clinical improvement and develop panel performance.

\section{Intergovernmental collaboration for resettlement of Australia-bound Syrian refugees}

Intergovernmental collaboration has been a major strength contributing to the health and wellbeing of Australia-bound Syrian refugees (Box 1). This collaboration was instrumental in generating an evidence based approach to improve Australia's PMHS, resulting in greater screening requirements (Table 1) and alignment with those of other IRHWG countries. These requirements enabled a broader identification of health conditions premigration, and were central to ensuring positive health and wellbeing outcomes for refugees settling in Australia.

Box 1. IRHWG responses to Syrian humanitarian crisis

The United Nations High Commissioner for Refugees called for resettlement states to accept Syrian refugees with serious medical conditions. ${ }^{19}$ In 2015 , the Australian Government announced a commitment to resettle an additional 12000 refugees fleeing Syria and Iraq. ${ }^{20}$ Other IRHWG member governments made similar commitments. This tripled PMHS caseloads in the region for $1 \mathrm{OM}$, as all five countries use the same IOM panel. In November 2015, Australia introduced additional requirements to improve settlement of Syrian refugees, such as increased vaccinations, mental health screening, treatment of skin conditions and identification of significant conditions.

The IRHWG exchanged information to assess PMHS capability in the region and met with the IOM to understand service delivery concerns. Australia and Canada jointly visited camps in Lebanon and Turkey, undertaking a capacity and capability assessment to assure the continuation of high-performing panels. The IRHWG encouraged the IOM's work with national TB programs to improve diagnostic practices, including funding mycobacteria growth indicator tubes. ${ }^{17}$ This collaboration enabled the IOM to scale up Syrian PMHS cases to more than 78000 in 2016, compared with 1500 in 2014. ${ }^{18}$ This ensured the timely arrival of Syrians settling in Australia without affecting the quality of screening.

PMHS processes are pivotal to early identification of health conditions to inform onshore continuity of care for Australia-bound refugees. Other IRHWG members' evidence, such as synopses of health concerns for 
Table 1. Australia's additional premigration health screening requirements for Syrian refugees

\begin{tabular}{ll}
\hline Requirement & Applicability \\
Mental health screening & All applicants \\
$\begin{array}{l}\text { Tuberculin skin test or } \\
\text { interferon gamma release }\end{array}$ & $\begin{array}{l}\text { Applicants aged } \geq 2 \text { to } \leq 11 \\
\text { assays (IGRA) test }\end{array}$ \\
Hepatitis B screening & \\
& $\begin{array}{l}\text { Applicants aged } \geq 11 \text { years } \\
\text { Applicants } \leq 10 \text { years who are } \\
\text { having an IGRA or any other } \\
\text { blood test should also be } \\
\text { tested for hepatitis B }\end{array}$
\end{tabular}

Developmental assessment Applicants aged $\leq 5$ years

Fitness to fly All applicants

\section{Medication and vaccination requirements}

Albendazole dose

Applicants aged $\geq 1$ years

Measles, mumps and rubella (MMR) vaccine

Applicants aged $\geq 9$ months to $\leq 54$ years

Diphtheria, tetanus, pertussis Applicants aged $\geq 6$ weeks to (DTP)/Haemophilus influenzae $\leq 11$ years

type b (Hib)/polio vaccine, or oral polio vaccines

Oral polio vaccine (or inactivated polio vaccine)

Current medications

Applicants aged $\geq 11$ years

At least 2 weeks supply given before departure

Canada-bound refugees and collated IRHWG best practices, shaped the additional requirements Australia introduced specifically for this cohort. These included broader premigration vaccinations, based on the US model, which meant that refugee children began child care more quickly and social security financial payments were accessed faster.

Mental health screening was also introduced for adults and children, reflecting UK processes and the expertise of Australian psychiatrists in identifying refugees requiring intervention and treatment. Onshore refugee healthcare providers have responded positively to the prompt linkage to mental health services postarrival. An evidence based evaluation of Australia's introduced mental health screening is now being planned. In addition, more extensive collection of premigration health information has assisted access to required health services and appropriate accommodation immediately on arrival.

\section{Conclusion}

The five IRHWG partners share a similar history of refugee resettlement within their countries, and all require a mechanism of formal health screening as part of the immigration process defined through legislation. The effectiveness of PMHS for settlement hinges on having the correct screening settings and delivering efficiently to a high clinical standard. As part of this intergovernmental collaboration, Australia gains a greater understanding of emerging refugee health issues based on partner experience and evidence, through information exchange, and learns collaboratively through exploring similarities and differences in refugee health screening. Furthermore, alignment between Australia and New Zealand leverages resourcing and internal expertise to improve the quality of health screening and services delivered to refugees, and diagnostic capability. The positive influence of the IRHWG collaboration on Australia's refugee screening policy contributes to premigration early intervention and continuity of care received by refugees settling in Australia to improve their settlement.

\section{Competing interests}

The authors were employees of the Department of Home Affairs and represented Australia on the IRHWG at the time of article submission.

\section{Author contributions}

Both authors contributed to writing, editing and reviewing this paper.

\section{References}

1. Australian Government Department of Home Affairs. Canberra: Department of Home Affairs. Fact sheet - Australia's refugee and humanitarian programme; [cited 2017 Sep]; [about 4 screens]. Available from: www.border.gov.au/about/corporate/information/factsheets/60refugee

2. Australian Government Department of Immigration and Border Protection. Discussion paper: Australia's humanitarian programme 2017-18. Canberra:

Department of Immigration and Border Protection; [cited 2017 Sep 18]. Available from: www.homeaffairs.gov.au/ ReportsandPublications/Documents/discussion-papers/ discussion-paper-humanitarian-programme_2017-18.pdf

3. Palinkas LA, Pickwell SM, Brandstein K, Clark TJ, Hill LL, Moser RJ, Osman A. The journey to wellness: stages of refugee health promotion and disease prevention. J Immigr Health. 2003;5(1):19-28. 
4. Hashemite Kingdom of Jordan Ministry of Health. Syrian crisis in Jordan: health needs assessment report. Amman (Jordan): Hashemite Kingdom of Jordan Ministry of Health; 2014 March. 53 p.

5. Douglas P, presenter. Migration medical assessments; a mechanism for public health benefit. International Conference of Migration, Social Disadvantage and Health; 11-15 Feb 2015; Melbourne, Australia.

6. Douglas P, Posey D, Zenner D, Robson J, Abubakar I, Giovinazzo G. Capacity strengthening through premigration tuberculosis screening programmes: IRHWG experiences. Int J Tuberc Lung Dis. 2017;21(7):737-45.

7. Paxton GA, Sangster KJ, Maxwell EL, McBride CR, Drewe $\mathrm{RH}$. Post-arrival health screening in Karen refugees in Australia. PloS One. 2012;7(5):e38194.

8. Wickramage K, Mosca D. Can migration health assessments become a mechanism for global public health good? Int J Environ Res Public Health. 2014;11:9954-63.

9. Australian Government Department of Home Affairs. Canberra: Department of Home Affairs. Fact Sheet - Health Requirement; [cited 2017 Sep 20]; [about 4 screens]. Available from: www.border.gov.au/about/ corporate/information/fact-sheets/22health

10. Dara M, Gushulak BD, Posey DL, Zellweger JP, Migliori $\mathrm{GB}$. The history and evolution of immigration medical screening for tuberculosis. Expert Rev Anti Infect Ther. 2013;11(2):137-46.

11. Mitchell T, presenter. Lead poisoning in Burmese refugee children: Tak province camps, Thailand. IRHWG Sixth Annual Conference 2009; 2-6 Nov 2009; Bangkok, Thailand.

12. Mitchell T, Jentes E, Ortega L, Scalia Sucosky M, Jefferies T, Bajcevic P, et al. Lead poisoning in United States-bound refugee children: Thailand-Burma border, 2009. Pediatrics. 2012;129(2):e392-9.
13. Australian Government Department of Immigration and Border Protection. Annual Report 2012-13. Canberra: Commonwealth of Australia; 2013 [cited 2017 Sep 20]. Available from: www.homeaffairs.gov.au/ ReportsandPublications/Documents/annual-reports/201213-diac-annual-report.pdf

14. White Z, Painter J, Douglas P, Abubakar I, Njoo H, Archibald C, et al. Immigrant arrival and tuberculosis among large immigrant- and refugee-receiving countries, 2005-2009. Tuberc Res Treat. 2017;2017:8567893.

15. Australian Government Department of Immigration and Border Protection. Departure health check instructions for refugee and special human programme entrants to Australia. Canberra: Department of Immigration and Border Protection; 2017. p. 14-5. (Internal document)

16. US Centers for Disease Control and Prevention and Australian Department of Immigration and Border Protection. Evaluation of Australia's malaria test and treat approach to refugees resettling from malaria endemic areas to Australia. Atlanta; 2015. (Internal document)

17. International Organization for Migration. IOM regional response to the Syria crisis situation report. Geneva: IOM; 2017 [cited 2017 Sep 19]. Available from: www.iom.int/ sites/default/files/situation_reports/file/IOM_Regional_ Response_to_the_Syria_Crisis_Sitrep_January_2017.pdf

18. International Organization for Migration, Mosca D, presenter. IOM health assessment programmes, 2016 updates. IRHWG Thirteenth Annual Conference 2017; 7-10 Mar 2017; Oxford, UK.

19. United Nations High Commissioner for Refugees. Addressing challenges in the resettlement of refugees with serious medical conditions and disabilities. Geneva: UNHCR; 2014. (Internal document)

20. Minister for Foreign Affairs. Canberra: Department of Foreign Affairs and Trade. The Syrian and Iraqi humanitarian crisis; 2015 September 9; [cited 2017 Sep 20]; [about 2 screens]. Available from: www.foreignminister.gov.au/releases/Pages/2015/jb_ mr_150909a.aspx

\section{Copyright: (c) (i) (-)}

(C) 2018 Martin and Douglas. This article is licensed under the Creative Commons Attribution-NonCommercial-ShareAlike 4.0 International Licence, which allows others to redistribute, adapt and share this work non-commercially provided they attribute the work and any adapted version of it is distributed under the same Creative Commons licence terms. See: www.creativecommons.org/licenses/by-nc-sa/4.0/ 